\title{
A Method for Calculating the Productivity of Simulated Moving Bed Chromatography Based on the Optimized Repeated Cyclic Operation Chromatography
}

\author{
Yukiteru SUGIYAMA, Noriko YOSHIMOTO, Shuichi YAMAMOTO ${ }^{\dagger}$ \\ Bio-Process Engineering Laboratory, Graduate School of Medicine and Biomedical Engineering Center (YUBEC) \\ 2-16-1 Tokiwadai, Ube City, Yamaguchi 755-8611, Japan
}

\begin{abstract}
A method for calculating the productivity of simulated moving bed (SMB) chromatography based on the optimized repeated cyclic operation (RCO) chromatography was proposed. As a model system, a two-component separation system was chosen, where the distribution coefficients were controlled by changing the mobile phase composition. First, the sample feed volume per bed volume and the mobile phase velocity for the optimized RCO were used for determining the two inlet and the two outlet flow rates and the two zone velocities. The same HETP vs. flow velocity equations were used both for RCO and SMB. By using the parameters determined numerical calculations were carried out for the two different differences in the distribution coefficients. When the difference in the distribution coefficients was large, the productivity value of RCO was higher than that of SMB. The productivity of SMB was slightly higher for a smaller difference in the distribution coefficients.
\end{abstract}

Keywords: batch chromatography, SMB, productivity, distribution coefficient, HETP

\section{1. 緒言}

抗体に代表されるタンパク質医薬品の製造に打いて は，細胞由来のタンパク質，DNA，ウイルスさらには， 製品であるタンパク質由来の凝集体や改変体を完全に 除去することが必要であり，複数回のクロマトグラ フィー操作が中心のダウンストリームプロセスが必要 となる。午のコストは全コストの $50 \%$ 以上を占めると いわ机ている [1-3].

食品産業ではクロマトグラフィーによる精密分離は 一般的ではない。これは，タンパク質医薬品のように 精密分離を必要とする高価な製品が少ないからである. しかしながら，食品に対して高機能性が期待されてお り，経済的に実用可能なクロマトグラフィープロセス の要求が増加していくと考えられる.

クロマトグラフィーの効率化すなわち生産性の向上

(受付 2017 年 9 月 25 日，受理 2018 年 1 月 29 日)

干755-8611 山口県宇部市常盤台 2 丁目 16-1

$\dagger$ Fax: 0836-85-9240, E-mail: shuichi@yamaguchi-u.ac.jp
には適切なモデルと評価方法が必要である.クロマト グラフィーは回分式操作であり，容易に生産性が定義 できる。一方，高い生産性が得られるとされている複 数本のカラムを切り替える(スイッチング) ことにより, 擬似的に連続操作をする方法 [擬似移動層, simulated moving bed (SMB) ] は, 操作変数が多いため操作条件 の設定が難しい。 また，生産性の定義も回分式とは異 なる，設計方法や最適化法について多くの論文が発表 されているにもかかわらず [4-14]，最適化された繰り 返し回分操作 (repeated cyclic operation, RCO) のク ロマトグラフィーと SMB の生産性比較は，ほとんど行 われて打らず，どのような条件で SMB の生産性がどの 程度向上するかについては明確ではない。

本研究では，等組成溶出クロマトグラフィーによる 2 成分分離（エタノール水移動相によるカテキン，エピ ガロカテキンガレートのポリスチレン樹脂逆相クロマ トグラフィー）をモデル系として，前報で提案した $\mathrm{RCO}[15]$ を基準とした標準型 4 ゾーン SMB の操作条 件の設定方法と生産性の計算方法を提案し，実験值に 基づいて両方法の生産性の比較を行った. 
2. 理

\section{論}

\subsection{RCO による 2 成分分離 $[15,16]$}

等組成（isocratic）溶出の 2 成分分離は，保持容量 $V_{\mathrm{R}}$ と HETP で記述できる。ここでは溶質の移動相固定 相間の分配係数 $K$ は一定（線形）であるとする.

$$
V_{\mathrm{R}}=F t_{\mathrm{R}}=V_{\mathrm{o}}+\left(V_{\mathrm{t}}-V_{\mathrm{o}}\right) K=V_{\mathrm{o}}(1+H K)
$$

ここで, $F$ は体積流量， $t_{\mathrm{R}}$ は保持時間， $V_{\mathrm{t}}$ はカラムベッ ド容量, $V_{\mathrm{o}}$ は空隙容量, $H=\left(V_{\mathrm{t}}-V_{\mathrm{o}}\right) / V_{\mathrm{o}}=(1-\varepsilon) / \varepsilon$ は 相体積比, $\varepsilon$ はカムのの空隙率である.

$$
\mathrm{HETP}=Z\left(\frac{\sigma}{t_{\mathrm{R}}}\right)^{2}=\frac{Z}{16}\left(\frac{W}{t_{\mathrm{R}}}\right)^{2}=Z\left(\frac{\sigma_{\mathrm{V}}}{V_{\mathrm{R}}}\right)^{2}
$$

ここで, $Z$ はカラムベッド長， $\sigma$ はピーク標準偏差， $\sigma_{\mathrm{V}}$ は体積基準のピーク標準偏差である。 $W=4 \sigma$ はべース ラインでのピーク幅である. HETP は移動相線速度 $u$ の関数として次式で表される.

$$
\mathrm{HETP}=A^{0}+C^{0} u
$$

ここで, $A^{0}$ と $C^{0}$ は定数である。移動相線速度 $u$ の増 加とともにピーク幅は広がる。また，式(3)で直接は計 算できないが，ピーク幅は試料容量 $V_{\mathrm{F}}\left(=F t_{\mathrm{F}}\right)$ の増加 でも広がる，少量のサンプルでのピーク幅 $\sigma_{\mathrm{V}_{0}}{ }^{2}$ からの $V_{\mathrm{F}}$ による増加は $20 \%$ 程度までは次式で計算できる。

$$
\sigma_{\mathrm{V}}^{2}=\sigma_{\mathrm{Vo}}^{2}+\frac{V_{\mathrm{F}}^{2}}{12}
$$

2 成分の分離の程度を評価するために次式で定義される 分離度 $R_{\mathrm{s}}$ が利用される。下付き 1 と 2 は，それぞれ成 分 1 と 2 を示す (組成 1 は最初に溶出する成分である).

$$
R_{\mathrm{s}}=\frac{2\left(t_{\mathrm{R}, 2}-t_{\mathrm{R}, 1}\right)}{W_{1}+W_{2}}
$$

式 (1) と式 (2)を式 (5) に代入して整理すると次式となる [17].

$$
R_{\mathrm{s}}=\frac{Z^{0.5}}{2} \frac{H\left(K_{2}-K_{1}\right)}{\left(\mathrm{HETP}_{1}\right)^{0.5}\left(1+H K_{1}\right)+\left(\mathrm{HETP}_{2}\right)^{0.5}\left(1+H K_{2}\right)}
$$

$R_{\mathrm{S}} \geqq 1.2$ では完全に分離し，ピークを三角形に近似した 場合は $R_{\mathrm{S}}=1.0$ で完全分離となる。例えば， $R_{\mathrm{S}}=1.0$ を 目的分離度とすると，それが成立する移動相線速度 $u$
と試料容量 $V_{\mathrm{F}}$ の組み合わせが存在する。このような等 分離度条件で，次式で定義される生産性 $P$ を計算する と，最大生産性 $P_{\mathrm{M}}$ を与える $u_{\mathrm{M}}$ が求まる.

$$
P=\frac{C_{0} V_{\mathrm{F}}}{V_{\mathrm{o}} t_{\mathrm{C}}}
$$

ここで， $C_{0}$ は原料濃度， $t \mathrm{c}$ はサイクル時間（分離に必 要な時間) である。繰り返し操作では，Fig. 1 でわかる ように成分 2 の溶出が終了する前に，次の試料注入を することで $t_{\mathrm{C}}$ を短くすることができる $\left(t_{\mathrm{C}}=t_{2 \mathrm{~b}}-t_{1 \mathrm{a}}\right)$. ここで， $t_{1 \mathrm{a}}$ は成分 1 の溶出開始時間， $t_{2 \mathrm{~b}}$ は成分 2 の溶 出終了時間である。このような RCO は，㛜密には回分 式ではなく擬似連続操作とよぶほうが適切である.

また，使用溶媒量を考慮した生産性は，次式で定義 できる。

$$
P_{1}=\frac{C_{0} V_{\mathrm{F}}}{V_{\mathrm{o}} t_{\mathrm{C}}} \frac{V_{\mathrm{o}}}{V_{\mathrm{C}}}=P \frac{V_{\mathrm{o}}}{V_{\mathrm{C}}}
$$

$V_{\mathrm{C}}$ は 1 サイクルあたりの溶媒供給量である. 吸着等温 線が線形のとき, 生産性は $C_{0}$ に比例するので, $P^{*}=$ $P / C_{0}, P_{1}^{*}=P_{1} / C_{0}$ と $C_{0}$ で規格化できる.

$$
\begin{gathered}
P^{*}=\frac{P}{C_{0}}=\frac{V_{\mathrm{F}}}{V_{\mathrm{o}} t_{\mathrm{C}}} \\
P_{1}^{*}=\frac{P_{1}}{C_{0}}=\frac{V_{\mathrm{F}}}{V_{\mathrm{o}} t_{\mathrm{C}}} \frac{V_{\mathrm{o}}}{V_{\mathrm{C}}}=\frac{V_{\mathrm{F}}}{V_{\mathrm{C}} t_{\mathrm{C}}}
\end{gathered}
$$

単位は $P^{*}\left[(\mathrm{~mL}\right.$-product $\left.)(\mathrm{mL}-\text { bed })^{-1} \mathrm{~min}^{-1}\right]=\left[\mathrm{min}^{-1}\right]$, $P_{1}^{*}\left[(\mathrm{~mL}\right.$-product $\left.)(\mathrm{mL} \text {-solvent })^{-1} \mathrm{~min}^{-1}\right]=\left[\mathrm{min}^{-1}\right]$ であ る（前報 [15] では，ある大きさのカラムの生産性の計 算に着目しているので，式 (8) と式 (10) は単位体積単位 時間あたりとしている)。

\section{2 複数カラム切り替えによる連続操作（SMB）}

前述の RCO では 1 本のカラムを利用している。複数 のカラムを切り替えることによる擬似的な連続クロマ トグラフィー操作がいくつかあるが，等組成 2 成分分 離に対してもっともよく知られているのはSMBであ る. SMB にもさまざまな改変型があるが [10]，ここで は標準型 4 ゾーン（4 カラム） SMB を考える。基本的 な操作を Fig. 2 に示す。ここで，移動相溶媒(D) はゾー ン 1 のカラムに, 試料 $(\mathrm{F})$ はゾーン 3 のカラムに供給さ

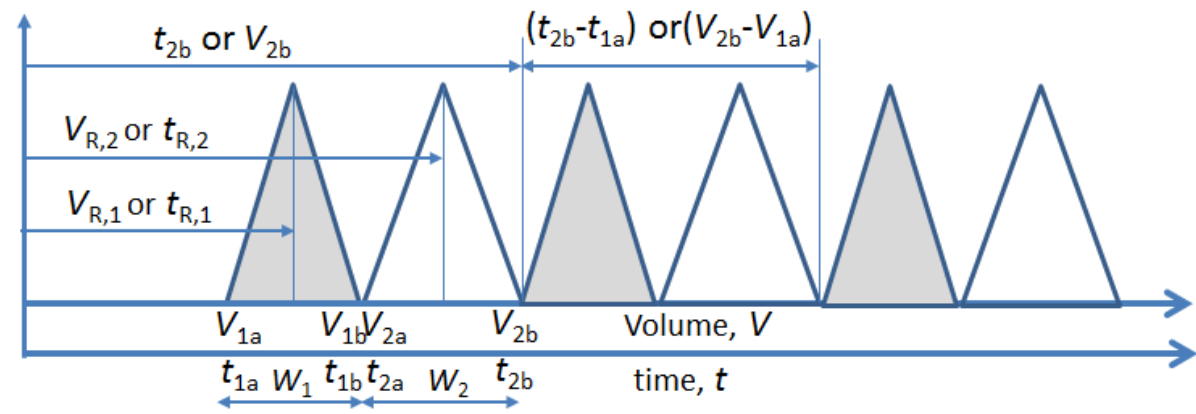

Fig. 1 Repeated cyclic operation (RCO) chromatography. 

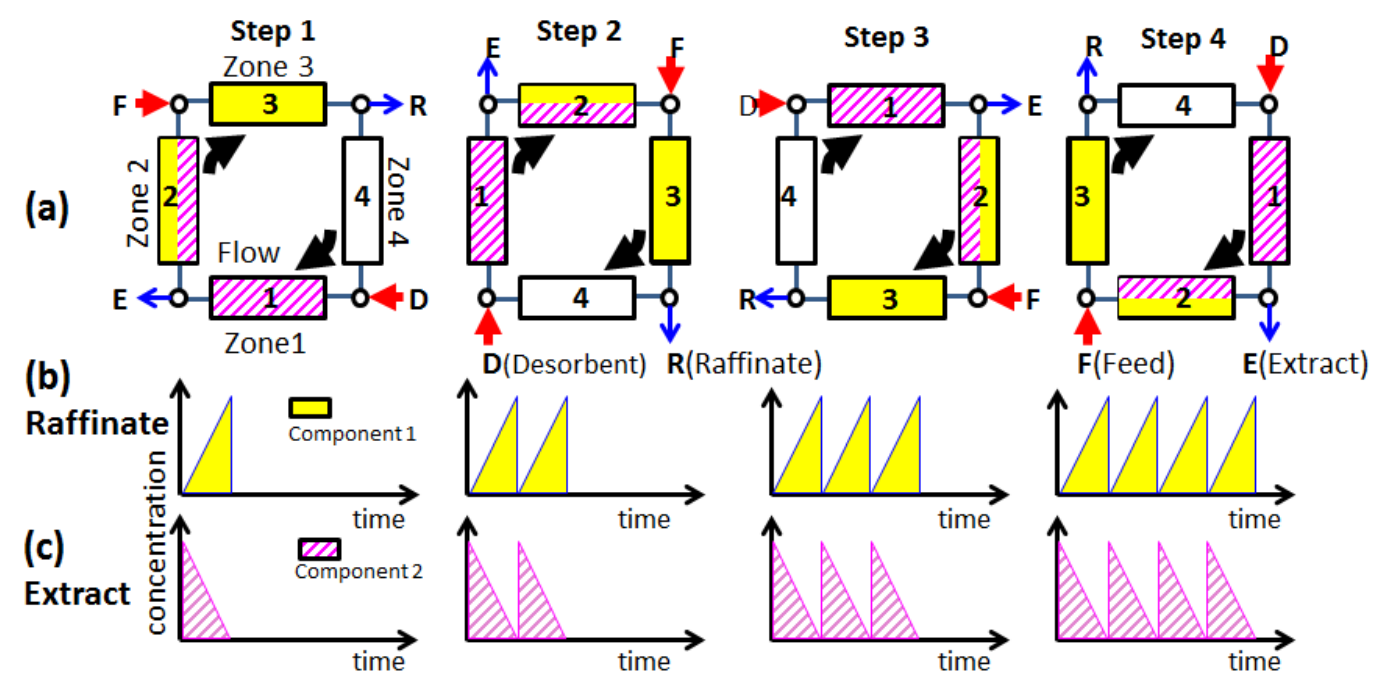

Fig. 2 Simulated moving bed (SMB) chromatography.

れ，エクストラクト $(\mathrm{E})$ 画分はゾーン 1 とゾーン 2 の間 から，ラフィネート $(\mathrm{R})$ 画分はゾーン 3 とゾーン 4 の間 から回収される。

$\mathrm{RCO}$ では流速 $u$ は一定であるが，SMB では各ゾーン の速度は異なる $\left(v^{(1)}, v^{(2)}, v^{(3)}, v^{(4)}\right)$ 。また，入口 2 か 所 $\left(v_{\mathrm{F}}, v_{\mathrm{D}}\right)$ と出口 2 か所の流速 $\left(v_{\mathrm{R}}, v_{\mathrm{E}}\right)$, さらには 切り替え時間 $t_{\mathrm{sw}}$ の合計 9 つの変数が存在する. カラム 長さ (ゾーン長さ) を固定しても 9 つの変数を最適化し, 最大生産性条件を探索することは容易ではない.

定常状態で 2 か所の入口と 2 か所の出口の流速には 式(11) が成立する.

$$
v_{\mathrm{F}}+v_{\mathrm{D}}=v_{\mathrm{R}}+v_{\mathrm{E}}
$$

分離を達成するためには各ゾーンの速度 $v^{(l)}$ は, Adachi[4] が提案している 4 つの不等式を満足するよう に設定しなければならない。これについては Triangle Theoryとして整理され，以下の記述が広く用いられて いる $[5,6]$.

$$
\begin{gathered}
m^{(l)=} \frac{v^{(l)}-\varepsilon v_{\mathrm{s}}}{(1-\varepsilon) v_{\mathrm{s}}} \quad l=1,2,3,4 \\
K_{2}<m^{(1)} \\
K_{1}<m^{(2)}<K_{2} \\
K_{1}<m^{(3)}<K_{2} \\
-\frac{1}{H}<m^{(4)}<K_{1}
\end{gathered}
$$

ここで, $m^{(l)}$ は各ゾーンの移動相と固定相の移動速度の 比を表わし，無次元化速度比（dimensionless flow-rate ratio）とよばれる。 $v_{\mathrm{s}}$ は固定相線速度であり，次式で 定義される.

$$
v_{\mathrm{s}}=\frac{Z}{4 t_{\mathrm{sw}}}
$$

ここで， $t_{\mathrm{sw}}$ はカラム切替え時間である. SMBでは原料 と溶媒供給および分離液の回収は連続的に行われる. $\mathrm{RCO}$ と SMB の変数は以下の式で関係づけられる.

$$
\begin{gathered}
V_{\mathrm{o}, \mathrm{SMB}}=A_{\mathrm{C}} Z_{\mathrm{SMB}} \varepsilon \\
t_{\mathrm{C}, \mathrm{SMB}}=n t_{\mathrm{SW}} \\
V_{\mathrm{F}, \mathrm{SMB}}=A_{\mathrm{C}} v_{\mathrm{F}} t_{\mathrm{C}, \mathrm{SMB}} \\
V_{\mathrm{C}, \mathrm{SMB}}=A_{\mathrm{C}} v_{\mathrm{D}} t_{\mathrm{C}, \mathrm{SMB}}
\end{gathered}
$$

$V_{\mathrm{o}, \mathrm{SMB}}$ は $\mathrm{SMB}$ の全カラムの空隙容積, $A_{\mathrm{C}}$ はカラム 断面積, $Z_{\mathrm{SMB}}$ は $\mathrm{SMB}$ の全カラム長さ, $t_{\mathrm{C}, \mathrm{SMB}}$ は $\mathrm{SMB}$ の 1 サイクル時間, $n$ はカラム本数 (=本検討では 4 本), $V_{\mathrm{C}, \mathrm{SMB}}$ は 1 サイクルあたりの溶媒供給量, $V_{\mathrm{F}, \mathrm{SMB}}$ は 1 サイクルあたりの原料供給量である。式(15)-(18)を式 （9）と式(10)に代入することにより，SMBの生産性は 以下の式で表される。

$$
\begin{gathered}
P_{\mathrm{SMB}}^{*}=\frac{V_{\mathrm{F}}}{V_{\mathrm{o}} t_{\mathrm{C}}}=\frac{A_{\mathrm{C}} v_{\mathrm{F}} t_{\mathrm{C}, \mathrm{SMB}}}{A_{\mathrm{C}} Z_{\mathrm{SMB}} \varepsilon t_{\mathrm{C}, \mathrm{SMB}}}=\frac{A_{\mathrm{C}} v_{\mathrm{F}}}{A_{\mathrm{C}} Z_{\mathrm{SMB}} \varepsilon}=\frac{v_{\mathrm{F}}}{Z_{\mathrm{SMB}} \varepsilon} \\
P_{1, \mathrm{SMB}}^{*}=\frac{V_{\mathrm{F}}}{V_{\mathrm{o}} t_{\mathrm{C}}} \frac{V_{\mathrm{o}}}{V_{\mathrm{C}}}=P_{\mathrm{SMB}}^{*} \frac{V_{\mathrm{o}}}{V_{\mathrm{C}, \mathrm{SMB}}}=P_{\mathrm{SMB}}^{*} \frac{Z_{\mathrm{SMB}} \varepsilon}{v_{\mathrm{D}} t_{\mathrm{C}, \mathrm{SMB}}} \\
=\frac{v_{\mathrm{F}}}{v_{\mathrm{D}}} \frac{1}{t_{\mathrm{C}, \mathrm{SMB}}}=\frac{v_{\mathrm{F}}}{v_{\mathrm{D}}} \frac{1}{4 t_{\mathrm{sw}}}=\frac{v_{\mathrm{F}}}{v_{\mathrm{D}}} \frac{v_{\mathrm{s}}}{Z_{\mathrm{SMB}}}
\end{gathered}
$$

本研究では， RCO に打ける最大生産性 $P_{\mathrm{M}}$ の操作条 件に関する結果を基にした SMB の運転条件の決定と生 産性の計算方法を提案する。

＜計算手順 $>$

はじめに RCO に打ける $P_{\mathrm{M}}$ を求める (1)- (3).

(1) 分配係数は 2 成分ともに一定である（本系では移動 相濃度 $I$ により值が決定される)。

(2) 2 成分の HETP は式 (3) で計算する $\left(A^{\mathrm{o}}, C^{\mathrm{o}}\right.$ はそれ ぞれの成分で異なる) 
(3) カラム長さ $Z$ の RCO において $P^{*}{ }_{\mathrm{M}}\left(P^{*}\right.$ の最大值) と なる移動相線速度 $u_{\mathrm{M}}$ と試料供給量 $V_{\mathrm{F}, \mathrm{M}}$ を求める. $\left(P_{\mathrm{M}}\right.$ の求め方はすでに報告しているように $[15,18]$, 単位時間使用溶媒量あたりの試料供給量が最大にな る $u$ と $V_{\mathrm{F}}$ を探索する方法である).

次に SMB のパラメータを順次決定していく.

(4) ゾーン 3 の線速度 $v^{(3)}$ は RCO の $u_{\mathrm{M}}\left(P^{*}{ }_{\mathrm{M}}\right.$ となる線 速度の最大值）と同じに設定する. $v^{(3)}=\varepsilon u_{\mathrm{M}}=v_{\mathrm{M}}$

(5) 分離パラメータ $m^{(2)}$ は式 (12) と式 (13) から適正な值 を決定する。

（6）試料（Feed）供給速度 $v_{\mathrm{F}}$ を以下の手順で計算する.

$\mathrm{SMB}$ カラム長さは均等に 4 分割する.

$$
\begin{gathered}
Z_{\mathrm{RCO}}=Z_{\mathrm{SMB}}=Z^{(1)}+Z^{(2)}+Z^{(3)}+Z^{(4)}=4 Z^{(1)} \\
P_{\mathrm{M}}^{*}=\frac{V_{\mathrm{F}}}{t_{\mathrm{C}} V_{\mathrm{o}}}=\frac{A_{\mathrm{C}} v_{\mathrm{F}}}{A_{\mathrm{C}} Z_{\mathrm{SMB}} \varepsilon}=\frac{v_{\mathrm{F}}}{Z_{\mathrm{SMB}} \varepsilon}
\end{gathered}
$$

$\left(V_{\mathrm{F}} / t_{\mathrm{C}}\right)$ は 1 サイクルあたりの試料供給量であり, $\mathrm{SMB}$ では $A_{\mathrm{C}} v_{\mathrm{F}}$ となる。これより，

$$
v_{\mathrm{F}}=Z_{\mathrm{SMB}} \varepsilon P^{*}{ }_{\mathrm{M}}
$$

(7) 溶媒あるいは移動相供給速度 $v_{\mathrm{D}}$ は， RCO と同じに なるように計算する。

$$
\begin{aligned}
& \frac{t_{\mathrm{F}}}{t_{\mathrm{C}}-t_{\mathrm{F}}}=\frac{v_{\mathrm{F}}}{v_{\mathrm{D}}} \\
& v_{\mathrm{D}}=\frac{v_{\mathrm{F}}\left(t_{\mathrm{C}}-t_{\mathrm{F}}\right)}{t_{\mathrm{F}}}
\end{aligned}
$$

(8) $v^{(2)}$ は $v^{(3)}=v_{\mathrm{M}}$ から $v_{\mathrm{D}}$ と等しくなる. RCOにおい て $V_{\mathrm{C}}=V_{\mathrm{D}}+V_{\mathrm{F}}$ なので

$v_{\mathrm{M}} t_{\mathrm{C}} A_{\mathrm{C}}=v_{\mathrm{D}} t_{\mathrm{C}} A_{\mathrm{C}}+v_{\mathrm{F}} t_{\mathrm{C}} A_{\mathrm{C}}$ となり $v_{\mathrm{M}}=v_{\mathrm{D}}+v_{\mathrm{F}}$

$$
v^{(2)}=v^{(3)}-v_{\mathrm{F}}=v_{\mathrm{M}}-v_{\mathrm{F}}=v_{\mathrm{D}}
$$

(9) $v_{\mathrm{s}}$ は分離パラメータ $m^{(2)}=\left(v^{(2)}-\varepsilon v_{\mathrm{s}}\right) /\left[(1-\varepsilon) v_{\mathrm{s}}\right]$ か ら次式で計算する.

$$
v_{\mathrm{s}}=\frac{v^{(2)}}{\varepsilon+(1-\varepsilon) m^{(2)}}
$$

(10) $t_{\mathrm{sw}}$ は, $t_{\mathrm{sw}}=Z_{\mathrm{SMB}} /\left(4 v_{\mathrm{s}}\right)$ で決定する.

(11) $v^{(1)}$ は, $\mathrm{HETP}_{\mathrm{RCO}}=\mathrm{HETP}_{\mathrm{SMB}}$ となるように式 (27)よ り計算する.

$$
v^{(1)}=\frac{2\left(\mathrm{HETP}-A^{\circ}\right)}{\mathrm{C}^{0}}+\frac{\left(v_{\mathrm{D}}+v_{\mathrm{F}}\right)}{2}-v^{(3)}
$$

（12） $v_{\mathrm{E}}$ を物質収支に基づき式 (28) で決定する.

$$
v_{\mathrm{E}}=v^{(1)}-v^{(2)}
$$

$(13) v^{(4)}$ は物質収支に基づくと $v_{\mathrm{E}}$ と等しくなる.

$$
v^{(4)}=v^{(1)}-v_{\mathrm{D}}=v^{(1)}-v^{(2)}=v_{\mathrm{E}}
$$

（14） $v_{\mathrm{R}}$ を物質収支に基づき式 (30)で決定する.

$$
v_{\mathrm{R}}=v^{(3)}-v^{(4)}
$$

(15) 以上の手順により決定されたすべてのパラメータ $\left(v^{(1)}, v^{(2)}, v^{(3)}, v^{(4)}, v_{\mathrm{D}}, v_{\mathrm{E}}, v_{\mathrm{F}}, v_{\mathrm{R}}, Z_{\mathrm{SMB}}, t_{\mathrm{sw}}\right)$ を用 いて SMB の数值シミュレーション計算を行い，純 度 $X_{\mathrm{SMB}}$ と回収率 $Y_{\mathrm{SMB}}$ を計算する。 $X_{\mathrm{SMB}}, Y_{\mathrm{SMB}}$ の 計算值が目標值 $(X, Y)$ を下回る場合は，式 $(23) の$ $v_{\mathrm{F}}$ を減少し，計算值が上回る場合は， $v_{\mathrm{F}}$ を増加し て目標值を達成するまで再計算する。

(16) 生産性を式 (9) と式 (10) で計算する.

\section{3. 結果と考察}

前報に打いてエタノール水移動相によるカテキン（成 分 1)，エピガロカテキンガレート（成分 2）のポリス チレン樹脂（Diaion HP20SS 逆相クロマトグラフィー） をモデル系として， RCO による生産性について検討し た。この系ではエタノール水移動相のエタノール濃度 $I$ が減少すると分配係数 $K_{1}, K_{2}$ と分配係数の差 $\left(K_{2}-K_{1}\right)$ が増加するので分離は容易になるが，使用溶媒量が増 える傾向となる。式 (10)で定義される生産性を計算し たところ $I=26 \%$ 付近で最大生産性が得られることが明 らかとなった [15]. I= $24 \%$ 扎よび $26 \%$ に打ける両成分
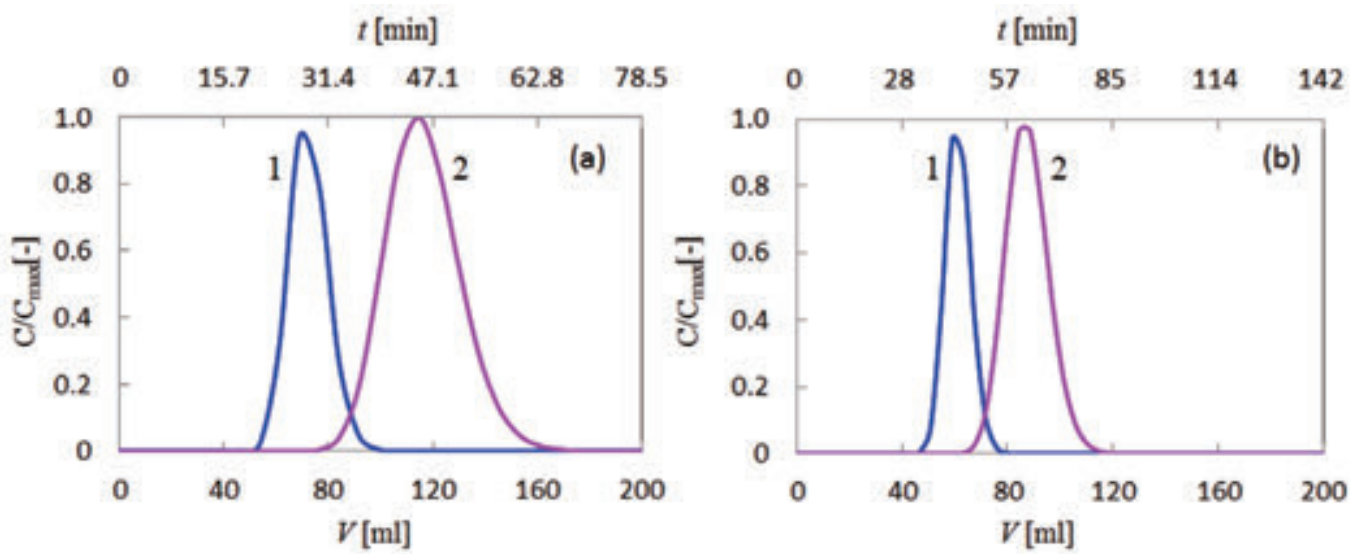

Fig. 3 Calculated elution curves of two components $(1,2)$ based on the experimental data for catechin (1) and epigallocatechin galate (2) on reversed phase chromatography. (a) $I=24 \%$ (b) $I=26 \%$ 
の溶出挙動の分離シミュレーションの結果を Fig. 3 に 示す.なお，本研究では $\varepsilon=0.400$ として計算した. $\mathrm{RCO}$ の等分離度条件 $\left(R_{\mathrm{S}}=1: X_{\mathrm{RCO}}=98 \%, Y_{\mathrm{RCO}}=\right.$ $98 \%$ ）に基づき，SMB の数值シミュレーション計算で は $X_{\mathrm{SMB}}=0.98 \pm 0.01, Y_{\mathrm{SMB}}=0.98 \pm 0.01$ および $X_{\mathrm{SMB}} Y_{\mathrm{SMB}}$ $=0.9625 \pm 0.025$ を目標值とした. 2.2 で提案した計算法 による $I=24 \%$ に対する計算手順と計算結果は以下とな る。まず， $K_{1}$ 扎よび $K_{2}$ は既報 [15] に従って実験的に 求めた相関式から計算した。 $I=24 \% ， 26 \%$ における $K_{1}$ 扎よび $K_{2}$ を用いて最適化した RCOの各パラメータを Table 1 に示す。 ここで，式(26)で用いる $m^{(2)}$ は，理論 的な分離条件では $m^{(2)}=K_{1}$ が成り立つが，分散がある 場合には $m^{(2)}>K_{1}$ となる. Triangle Theoryを利用し た既往 [10] では，打よそ $1.5 K_{1}>m^{(2)}>K_{1}$ の範囲に抒 いて最大生産性が検討されており，本研究では $m^{(2)}=$ $1.2 K_{1}$ を選択した。 これらの值を使用して順次パラメー タの值を決定する．以下に $I=24 \%$ のときの計算手順を まとめる.

$$
\begin{aligned}
& Z^{(1)}=Z^{(2)}=Z^{(3)}=Z^{(4)}=Z_{\mathrm{RCO}} / 4 \quad=7.5 \mathrm{~cm} \\
& P^{*}{ }_{\mathrm{M}}=V_{\mathrm{F}} /\left(t_{\mathrm{C}} V_{\mathrm{o}}\right) \quad=9.4 \times 10^{-3} \mathrm{~min}^{-1} \\
& v_{\mathrm{F}}=P^{*}{ }_{\mathrm{M}} Z_{\mathrm{SMB}} \varepsilon \quad \quad=0.113 \mathrm{~cm} \cdot \mathrm{min}^{-1} \\
& v_{\mathrm{D}}=v_{\mathrm{F}}\left(t_{\mathrm{C}}-t_{\mathrm{F}}\right) / t_{\mathrm{F}} \quad=2.57 \mathrm{~cm} \cdot \mathrm{min}^{-1} \\
& v^{(3)}=v_{\mathrm{M}} \quad=2.68 \mathrm{~cm} \cdot \mathrm{min}^{-1} \\
& v^{(2)}=v_{\mathrm{D}} \quad=2.57 \mathrm{~cm} \cdot \mathrm{min}^{-1} \\
& m^{(2)}=1.2 K_{1} \quad=4.20 \\
& v_{\mathrm{s}}=v^{(2)} /\left(\varepsilon+(1-\varepsilon) 1.2 K_{1}\right) \quad=0.88 \mathrm{~cm} \cdot \mathrm{min}^{-1} \\
& t_{\mathrm{sw}}=Z /\left(4 v_{\mathrm{s}}\right) \quad=8.53 \mathrm{~min} \\
& v^{(1)}=2\left(\operatorname{HETP}_{1, \mathrm{RCO}}-A^{\mathrm{o}}\right) / C^{\mathrm{o}}+\left(v_{\mathrm{F}}+v_{\mathrm{D}}\right) / 2-v^{(3)} \\
& =4.24 \mathrm{~cm} \cdot \mathrm{min}^{-1} \\
& v_{\mathrm{E}}=v^{(1)}-v^{(2)} \quad=1.67 \mathrm{~cm} \cdot \mathrm{min}^{-1} \\
& v^{(4)}=v_{\mathrm{E}} \quad=1.67 \mathrm{~cm} \cdot \mathrm{min}^{-1} \\
& v_{\mathrm{R}}=v^{(3)}-v^{(4)} \quad=1.01 \mathrm{~cm} \cdot \mathrm{min}^{-1}
\end{aligned}
$$

これらの值を使用して付録に示す SMBのシミュレー
ションを行ったところ，エクストラクト画分の成分 2 について, $X_{\mathrm{SMB}}=97.4 \%, Y_{\mathrm{SMB}}=96.3 \%, X_{\mathrm{SMB}} Y_{\mathrm{SMB}}=0.939$ であった。目標值を達成できていないので，流速を遅 くして分離効率を上げる必要があるが，生産性は低下 する．同様な計算を $I=26 \%$ にいても行った。その結 果を $I=24 \%$ の值とともに Table 1 にまとめる. $I=26 \%$ では, $X_{\mathrm{SMB}}=98.5 \%, Y_{\mathrm{SMB}}=98.6 \%, X_{\mathrm{SMB}} Y_{\mathrm{SMB}}=0.971$ であった，目標值より高いので $v_{\mathrm{F}}$ を増やして計算をし， $v_{\mathrm{F}}=0.084 \mathrm{~cm} \cdot \mathrm{min}^{-1}, \quad v_{\mathrm{D}}=1.40 \mathrm{~cm} \cdot \mathrm{min}^{-1}, t_{\mathrm{sw}}=13.3 \mathrm{~min}$ にて以下の結果を得た。

$$
\begin{aligned}
& X_{\mathrm{SMB}}=98.1 \%, Y_{\mathrm{SMB}}=97.9 \%, X_{\mathrm{SMB}} Y_{\mathrm{SMB}}=0.960 \\
& P^{*}{ }_{\mathrm{SMB}}=v_{\mathrm{F}} /\left(Z_{\mathrm{SMB}} \varepsilon\right)=7.0 \times 10^{-3} \mathrm{~min}^{-1} \\
& P_{1}^{*}{ }_{\mathrm{SMB}}=\left(v_{\mathrm{F}} / v_{\mathrm{D}}\right) /\left(4 t_{\mathrm{sw}}\right)=1.1 \times 10^{-3} \mathrm{~min}^{-1}
\end{aligned}
$$

$P_{\mathrm{SMB}}^{*}$ は RCO の生産性 $P^{*}=5.7 \times 10^{-3} \mathrm{~min}^{-1}$ に対して 1.23 倍, $P_{1}^{*}$, SMB は RCO の生産性 $P_{1}^{*}=1.3 \times 10^{-3} \mathrm{~min}^{-1}$ に対して 0.87 倍であった。

逆相系，イオン交換，踈水性相互作用クロマトグラ フィーに扔いては，移動相組成により分配係数と分配 係数差を制御することができる。 SMB は，難しい 2 成 分分離すなわち，分配係数の差 $\left(K_{2}-K_{1}\right)$ が小さい分 離において効率的な方法であると主張されている [3]. $\left(K_{2}-K_{1}\right)$ の值が 1 よりも大きく, 物質移動が速い (HETP が小さい）ときは，本研究で示したようにRCO の生産 性が SMB より高くなる場合もある.

$\mathrm{SMB}$ と回分式クロマトグラフィーの性能あるいは生 産性比較については比較の基準があいまいなので正確な 判定ができていない. SMB が 2-3 倍高い生産性である と結論している論文もあるが [11]，対象の回分式が十 分に最適化されていない，分離条件に依るがそれほどの 差がない [8,9]，あるいは大スケールによりメリットが でる [10] という報告もある。生産性のみに着目したが, $\mathrm{SMB}$ は装置が複雑であり初期投資についても十分検討 しておく必要がある。初期投資を考えると 5 年以上の運

Table 1 Parameter values for optimized RCO and SMB.

Repeated cyclic operation (RCO) optimized conditions for $R_{\mathrm{S}}=1\left(X_{\mathrm{RCO}}=98 \%, Y_{\mathrm{RCO}}=98 \%\right)$

\begin{tabular}{ccccccccccccccc}
\hline $\begin{array}{c}I \\
\%\end{array}$ & $\begin{array}{c}K_{1} \\
-\end{array}$ & $\begin{array}{c}K_{2} \\
-\end{array}$ & $\begin{array}{c}u \\
\mathrm{~cm} \cdot \mathrm{min}^{-1}\end{array}$ & $\begin{array}{c}V_{\mathrm{F}} \\
\mathrm{mL}\end{array}$ & $\begin{array}{c}t_{\mathrm{C}} \\
\mathrm{min}\end{array}$ & $\begin{array}{c}t_{\mathrm{F}} \\
\mathrm{min}\end{array}$ & $\begin{array}{c}\mathrm{HETP}_{1} \\
\mathrm{~cm}\end{array}$ & $\begin{array}{c}\mathrm{HETP}_{2} \\
\mathrm{~cm}\end{array}$ & $\begin{array}{c}Z \\
\mathrm{~cm}\end{array}$ & $\begin{array}{c}N_{1} \\
-\end{array}$ & $\begin{array}{c}N_{2} \\
-\end{array}$ & $\begin{array}{c}P^{*} \times 10^{3} \\
\min ^{-1}\end{array} \begin{array}{c}P_{1}^{*} \times 10^{3} \\
\mathrm{~min}^{-1}\end{array}$ \\
\hline 24 & 3.5 & 5.99 & 6.7 & 3.6 & 33.2 & 1.4 & 0.31 & 0.44 & 30.0 & 97 & 69 & 9.4 & 1.3 \\
26 & 2.88 & 4.39 & 3.7 & 2.35 & 36.4 & 1.67 & 0.19 & 0.25 & 30.0 & 161 & 118 & 5.7 & 1.3 \\
\hline
\end{tabular}

Simulated moving bed (SMB)

\begin{tabular}{cccccccccccccccc}
\hline $\begin{array}{c}I \\
\%\end{array}$ & $\begin{array}{c}v_{\mathrm{F}} \\
\mathrm{cm} \cdot \mathrm{min}^{-1}\end{array}$ & $\begin{array}{c}v_{\mathrm{D}} \\
\mathrm{cm} \cdot \mathrm{min}^{-1}\end{array}$ & $\begin{array}{c}v_{\mathrm{E}} \\
\mathrm{cm} \cdot \mathrm{min}^{-1}\end{array}$ & $\begin{array}{c}v_{\mathrm{R}} \\
\mathrm{cm} \cdot \mathrm{min}^{-1}\end{array}$ & $\begin{array}{c}v^{(1)} \\
\mathrm{cm} \cdot \mathrm{min}^{-1}\end{array}$ & $\begin{array}{c}v^{(2)} \\
\mathrm{cm} \cdot \mathrm{min}^{-1}\end{array}$ & $\begin{array}{c}v^{(3)} \\
\mathrm{cm} \cdot \mathrm{min}^{-1}\end{array}$ & $\begin{array}{c}v^{(4)} \\
\mathrm{cm} \cdot \mathrm{min}^{-1} \mathrm{~cm} \cdot \mathrm{min}^{-1}\end{array}$ & $\begin{array}{c}v_{\mathrm{sw}} \\
\mathrm{min}\end{array}$ & $\begin{array}{c}Z \\
\mathrm{~cm}\end{array}$ & $\begin{array}{c}X_{\mathrm{SMB}} \\
\%\end{array}$ & $\begin{array}{c}Y_{\mathrm{SMB}} \\
\%\end{array}$ & $\begin{array}{c}X_{\mathrm{SMB}} Y_{\mathrm{SMB}} \\
-\end{array}$ \\
\hline 24 & 0.113 & 2.57 & 1.67 & 1.01 & 4.24 & 2.57 & 2.68 & 1.67 & 0.88 & 8.53 & 30.0 & 97.4 & 96.3 & 0.939 \\
26 & 0.068 & 1.41 & 1.10 & 0.38 & 2.51 & 1.41 & 1.48 & 1.10 & 0.57 & 13.2 & 30.0 & 98.5 & 98.6 & 0.971 \\
\hline
\end{tabular}


転が必要との指摘もある [12]. また，4ゾーン以外の

SMB も開発されて打り，単純な比較は難しい [19].

ここで提案した方法はSMB の 8 個の流速のうち 6 個 を最適化した RCO の操作条件に基づくことにより設定 している。生産性は純度と回収率の設定值や，目的成 分と不純物の構成比率によっても大きく変化する. 本 提案方法を用いて, 広い条件下での SMB と RCO との 生産性の比較をすることにより，乥れぞれの方法のメ リットがでる操作条件あるいはクロマトグラフィー条 件が明確になることが期待される.

\section{付録 SMB の数値計算方法}

$\mathrm{SMB}$ の数值シミュレーションは以下の基礎式を有限 差分化して数値計算することにより行った.

$$
\begin{array}{ll}
\text { 移動相 } & \frac{\partial C}{\partial t}+H \frac{\partial \overline{C_{\mathrm{s}}}}{\partial t}=-u \frac{\partial C}{\partial z} \\
\text { 固定相 } & \frac{\partial \overline{C_{\mathrm{s}}}}{\partial t}=K_{\mathrm{s}}\left(K C-\overline{C_{\mathrm{s}}}\right)
\end{array}
$$

移動相では混合拡散を無視しており，固定相は総括物 質移動係数 $K_{\mathrm{s}}$ による linear driving force モデルを使用 している. $C$ は移動相での溶質濃度, $\overline{C_{\mathrm{s}}}$ は固定相での 溶質平均濃度である。

$K_{\mathrm{s}}$ と HETP は以下の式で関係づけられる.

$$
K_{\mathrm{s}}=\frac{2 H K}{(1+H K)^{2}}\left(\frac{u}{\mathrm{HETP}}\right)
$$

境界条件は下記となる。

$$
\begin{gathered}
C_{\mathrm{i}}{ }^{(l)}(z, 0)=C_{\mathrm{i}}{ }^{(l+1)}\left(z, t_{\mathrm{sw}}\right), l=1,2,3 \\
C_{\mathrm{s}, \mathrm{i}}{ }^{(l)}(z, 0)=C_{\mathrm{s}, \mathrm{i}}{ }^{(l+1)}\left(z, t_{\mathrm{sw}}\right), l=1,2,3 \\
C_{\mathrm{i}}{ }^{(4)}(z, 0)=C_{\mathrm{i}}{ }^{(1)}\left(z, t_{\mathrm{sw}}\right) \\
C_{\mathrm{s}, \mathrm{i}}{ }^{(4)}(z, 0)=C_{\mathrm{s}, \mathrm{i}}{ }^{(1)}\left(z, t_{\mathrm{sw}}\right)
\end{gathered}
$$

下記の条件も成立しなければならない。

$$
\begin{gathered}
C_{\mathrm{i}}{ }^{(l)}(z, t)=C_{\mathrm{i}}{ }^{(l+1)}(0, t), l=1,3 \\
u_{\mathrm{i}}{ }^{(2)} C_{\mathrm{i}}{ }^{(2)}(z, t)+u_{\mathrm{F}} C_{\mathrm{F}, \mathrm{i}}=u_{\mathrm{i}}{ }^{(3)} C_{\mathrm{i}}{ }^{(3)}(0, t) \\
u_{\mathrm{i}}{ }^{(4)} C_{\mathrm{i}}{ }^{(4)}(z, t)=u_{\mathrm{i}}{ }^{(1)} C_{\mathrm{i}}{ }^{(1)}(0, t)
\end{gathered}
$$

以上の計算を Kawajiri らが開発した MATLAB による パッケージを改訂して計算した [14].

\section{Nomenclature}

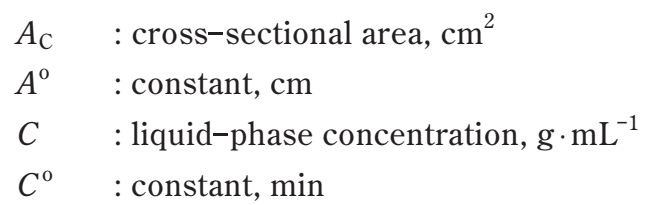

$C_{0} \quad$ : initial concentration, $\mathrm{g} \cdot \mathrm{mL}^{-1}$

$C_{s} \quad$ : average stationary phase concentration, $\mathrm{g} \cdot \mathrm{mL}^{-1}$

$F \quad$ : volumetric flow rate, $\mathrm{mL} \cdot \mathrm{min}^{-1}$

$H \quad$ : volumetric phase ratio, -

HETP : hight equivalent theoretical plate, $\mathrm{cm}$

$I \quad$ : ethanol concentration, \%

$K \quad$ : distribution coefficient, -

$K_{\mathrm{s}} \quad$ : overall mass transfer coefficient, $\min ^{-1}$

$m$ : dimensionless flow-rate ratio, -

$n \quad$ : number of columns, -

$P^{*} \quad$ : amount of the product obtained per unit bed volume per cycle time, $\min ^{-1}$

$P^{*}{ }_{\mathrm{M}} \quad$ : maximum amount of the product obtained per unit bed volume per cycle time for RCO, $\min ^{-1}$

$P_{\text {SMB }}^{*}$ : amount of the product obtained per unit bed volume per cycle time for SMB, $\min ^{-1}$

$P_{1}{ }^{*} \quad$ : amount of the product obtained per unit bed volume per unit solvent per cycle time, $\min ^{-1}$

$R_{\mathrm{S}} \quad$ : resolution, -

$t \quad$ : time, $\min$

$t_{\mathrm{C}} \quad:$ cycle time, $\min$

$t_{\mathrm{F}} \quad$ : feed time, min

$t_{\mathrm{R}} \quad$ : retention time, min

$t_{\mathrm{sw}} \quad:$ column switching time, min

$u \quad:$ linear mobile phase velocity, $\mathrm{cm} \cdot \mathrm{min}^{-1}$

$v \quad$ : superficial linear velocity, $\mathrm{cm} \cdot \mathrm{min}^{-1}$

$V_{\mathrm{C}} \quad$ : cycle elution volume, $\mathrm{mL}$

$V_{\mathrm{F}} \quad$ : feed volume, $\mathrm{mL}$

$V_{\mathrm{R}} \quad$ : retention volume, $\mathrm{mL}$

$V_{\mathrm{t}} \quad$ : column bed volume, $\mathrm{mL}$

$V_{\mathrm{o}} \quad$ : column void volume, $\mathrm{mL}$

$v_{\mathrm{s}} \quad:$ velocity of the stationary phase, $\mathrm{cm} \cdot \mathrm{min}^{-1}$

$W \quad$ : peak width at the base line, min

$X \quad$ : purity, \%

$Y \quad:$ yield, $\%$

$Z \quad$ : column length, $\mathrm{cm}$

Greek

$\varepsilon \quad$ : void fraction, -

$\sigma \quad$ : standard deviation, $\mathrm{s}$

\section{Subscripts}

$\mathrm{a}, \mathrm{b} \quad$ : start and end position of elution curve

D, E, F, R : abbreviation of Desorbent, Extract, Feed,

Raffinate

$i \quad$ : component $i$

Superscripts

$l \quad:$ zone number for SMB 


\section{References}

1) M. Ladisch; Reversed phase chromatography, Bioseparations Engineering, Principles, Practice. and Economics. New York, NY, Wiley (2001).

2) G. Carta, A. Jungbauer; Protein Chromatography. Weinheim, Wiley-VCH (2010).

3) G. H. Roger, P. Todd, S. R. Rudge, D. P. Petrides, Bioseparations Science and Engineering, Oxford University Press (2003).

4) S. Adachi; Simulated moving-bed chromatography for continuous separation of two components and its application to bioreactors. J. Chromatogr. A, 658, 271-282 (1994).

5) A. Rajendran, G. Paredes, M. Mazzotti; Simulated moving bed chromatography for the separation of enantiomers. J. Chromatogr. A, 1216, 709-738 (2009).

6) F. D. Antia; "A simple approach to design and control of simulated moving bed chromatographs. In Rathore A, Velayudhan A, editors. Scale-up and optimization in preparative chromatography" principles and biopharmaceutical applications. Dekker, 2002, p.173-201.

7) K. Hashimoto, Y. Shirai, S. Adachi, M. Horie; Comparison of efficiency in separation of maltose and glucose between conventional batch chromatography and simulated movingbed adsorber (in Japanese). Kagaku Kougaku Ronbunshu, 17, 623-626 (1991).

8) J. Strube, S. Haumreisser, H. Schmidt-Traub, M. Schulte, R. Ditz; Comparison of batch elution and continuous simulated moving bed chromatography. Org. Process Res. Dev., 2, 305-319 (1998)

9) A. Seidel-Morgenstern; Optimization and comparison of different modes of preparative chromatography. Analusis, 26, 46-55 (1998).

10) A. Jupke, A. Epping, H. Schmidt-Traub; Optimal design of batch and simulated moving bed chromatographic separation processes. J. Chromatogr. A., 944, 93-117 (2002).

11) G. Paredes, M. Mazzotti; Optimization of simulated moving bed and column chromatography for a plasmid DNA purification step and for a chiral separation. J. Chromatogr. A., 1142, 56-68 (2007).

12) S. Chan, N. Titchener-Hooker, E. Sorenson; Optimal economic design and operation of single- and multi-column chromatographic processes. Biotechnol. Prog., 24, 389-401 (2008).

13) J. Siitonen, T. Sainio; Unified design of chromatographic sep- aration processes. Chem. Eng. Sci., 122, 436-451 (2015).

14) B. Sreedhar, Y. Kawajiri; Multi-column chromatographic process development using simulated moving bed superstructure and simultaneous optimization - Model correction framework. Chem. Eng. Sci., 116, 428-441 (2014).

15) N. Yoshimoto, Y. Sugiyama, S. Yamamoto; A simple method for calculating the productivity of polyphenol separations by polymer-based chromatography. Biosci. Biotech. Biochem., 81, 812-816 (2017).

16) N. Yoshimoto, S. Yamamoto; "Simplified methods based on mechanistic models for understanding and designing chromatography processes for proteins and other biological products -Yamamoto Models and Yamamoto Approachin Preparative chromatography for separation of proteins" Chapter 4, A. Staby, A. S. Rathore, S. Ahuja ed., Wiley, 2017, pp.111- 157.

17) M.Hosono, R. Maeda, N.Yoshimoto, S. Yamamoto; Rational method for designing efficient chromatography processes based on the iso-resolution curve. Chem. Eng. Technol., 35, 198-203 (2012).

18) S. Yamamoto, M. Nomura; Predicting the performance of gel-filtration chromatography of proteins. J. Chromatogr. A, 512, 77-87 (1990).

19) Y. Sugiyama, N. Yoshimoto, S. Yamamoto; Continuous chromatographic separation processes by using a column switching technique (in Japanese), Jpn. J. Food Eng., 18, A9-A12 (2017).

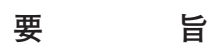

最適化された繰り返しクロマトグラフィー $(\mathrm{RCO})$ の操作条件に基づいた連続クロマトグラフィー（擬似 移動層 SMB）の操作条件扎よび生産性の計算方法を提 案した。移動相組成により分配係数を変化させること ができる 2 成分分離をモデル系とした，最初に， RCO の試料負荷量, 流速に基づいて SMB の 8 流速のうち, 入口 2 か所, 出口 2 か所, ゾーン 2 か所を決定した. $\mathrm{RCO}$ と SMB のどちらにも同じ HETP と線速度の関係 式を使用した。決定された変数を用いて SMB シミュ

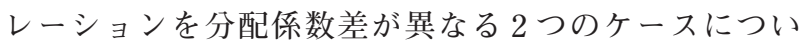
て実行した．分配係数差が大きいときは RCO の生産性 が高く，小さいときはSMB の生産性が高いという結果 が得られた。本方法を用いて，広範な条件に打ける $\mathrm{RCO}$ と SMB の生産性比較をすることにより，さらな る知見が得られると期待される. 